\title{
Comparison of the microalgal community within fast ice at two sites along the Ross Sea coast, Antarctica
}

\author{
K.G. RYAN ${ }^{1 *}$, E.N. HEGSETH ${ }^{2}$, A. MARTIN ${ }^{1}$, S.K. DAVY ${ }^{1}$, R. O'TOOLE ${ }^{1}$, P.J. RALPH ${ }^{3}$, A. MCMINN ${ }^{4}$ and \\ C.J. THORN ${ }^{1}$ \\ ${ }^{1}$ Victoria University of Wellington, PO Box 600, Wellington, New Zealand \\ ${ }^{2}$ The Norwegian College of Fishery Science, University of Tromsø, 9037 Tromsø, Norway \\ ${ }^{3}$ Research Institute for Water and Environmental Resource Management, Department of Environmental Sciences, University of Technology, \\ Sydney, PO Box 123 Broadway, Sydney, NSW 2007, Australia \\ ${ }^{4}$ Institute of Antarctic and Southern Ocean Studies, University of Tasmania, Box 252-77 Hobart, TAS 7001, Australia \\ *Ken.Ryan@vuw.ac.nz
}

\begin{abstract}
Diverse microbial communities survive within the sea ice matrix and are integral to the energy base of the Southern Ocean. Here we describe initial findings of a four season survey (between 1999-2004) of community structure and biomass of microalgae within the sea ice and in the underlying water column at Cape Evans and Cape Hallett, in the Ross Sea, Antarctica as part of the Latitudinal Gradient Project. At Cape Evans, bottom-ice chlorophyll $a$ levels ranged from 4.4 to $173 \mathrm{mg} \mathrm{Chl} a \mathrm{~m}^{-2}$. Dominant species were Nitzschia stellata, N. lecointei, and Entomoneis kjellmanii, while the proportion of Berkeleya adeliensis increased steadily during spring. Despite being obtained later in the season, the Cape Hallett data show considerably lower standing stocks of chlorophyll ranging from 0.11 to $36.8 \mathrm{mg} \mathrm{Chl} a \mathrm{~m}^{-2}$. This difference was attributed to a strong current, which may have ablated much of the bottom ice biomass and provided biomass to the water below. This loss of algae from the bottom of the ice may explain why the ice community contributed only $2 \%$ of the standing stock in the total water column. Dominant species at Cape Hallett were Nitzschia stellata, Fragilariopsis curta and Cylindrotheca closterium. The low biomass at Cape Hallett and the prevalence of smaller-celled diatoms in the bottom ice community indicate that the ice here is more typical of pack ice than fast ice. Further data will allow us to quantify and model the extent to which ice-driven dynamics control the structure and function of the sea ice ecosystem and to assess its resilience to changing sea ice conditions.
\end{abstract}

Received 2 February 2006, accepted 12 June 2006

Key words: biomass, Cape Evans, Cape Hallett, Latitudinal Gradient Project, pack ice, primary production, Victoria Land

\section{Introduction}

Sea ice is a predominant feature of polar oceans and exerts a unique influence on Antarctic marine ecosystems. Although the sea ice that forms annually around the Antarctic continent represents a harsh physico-chemical environment with steep gradients in temperature, light, salinity, and nutrient concentrations (Arrigo \& Sullivan 1992, McMinn et al. 1999a), diverse microbial communities are able to survive in the brine inclusions and interstices of the sea ice matrix. Microalgae are a critical component of this community, and the sea ice provides a platform from which the algae can remain suspended in the upper ocean where light is sufficient for net growth (Arrigo \& Thomas 2004). The most prominent microalgae are pennate diatoms and efforts to investigate the biology of sea ice have focused on the composition, physiology and ecology of the species that dominate fast ice assemblages (e.g. Garrison 1991, Arrigo et al. 1998, McMinn et al. 2000, Thomas et al. 2001, Ryan et al. 2002, Trenerry et al. 2002) and which reach such concentrations that their photosynthetic pigments discolour the ice during the summer (Thomas \& Dieckmann 2002,
Mock \& Thomas 2005). The contribution of microalgae to primary production in ice-covered regions is thought to be between 10-30\% (Legendre et al. 1992, Arrigo et al. 1998). Biomass proxies such as chlorophyll $a(\mathrm{Chl} a)$ and particulate organic carbon and nitrogen are widely used measurements to characterize sea ice microbial communities and allow quantification of the microalgal biomass in sea ice or the water column.

In the Ross Sea, ice algal studies started in the 1980s, and the most extensively studied area is McMurdo Sound (Arrigo \& Thomas 2004). Some studies have also been undertaken further north at Terra Nova Bay (Stoecker et al. 1991, Buck et al. 1992, Palmisano \& Garrison 1993, Andreoli et al. 2000). The development, abundance and primary production of ice algae have been studied (Sullivan et al. 1982, 1985, Palmisano \& Sullivan 1983), and the effects of light perturbation on algal growth were included later (Palmisano et al. 1985, Grossi et al. 1987). Studies have been performed on algae in the platelet ice layer (Arrigo et al. 1993), and possible effects of UV radiation were assessed in the 1990s (Ryan \& Beaglehole 1994, 
McMinn 1997, McMinn et al. 1999a). Investigations of nutrient stress (McMinn et al. 1999b) and new methods for production studies have been introduced (McMinn \& Ashworth 1998, McMinn et al. 2000). However, relatively few studies have quantified community structure with respect to species or major taxa (Grossi \& Sullivan 1985, McMinn 1997, Garrison et al. 2005).

The Victoria Land mountain chain and coastline within the Ross Sea region contains the most extensive coastal gradient in Antarctica, which stretches from Cape Adare $\left(71^{\circ} \mathrm{S}\right)$ in the north, to the southern end of the Ross Ice Shelf $\left(86^{\circ} \mathrm{S}\right)$, and includes a variety of marine, terrestrial and freshwater habitats. Important environmental factors including solar radiation (annual radiation, UV radiation), temperature, day length and sea ice cover vary predictably along this gradient and are likely to exert a significant influence on ecological processes (Peterson \& HowardWilliams 2001, Howard-Williams et al. 2006). The Latitudinal Gradient Project (LGP) aims to develop an understanding of the ecosystems that exist along the Victoria Land coastline and to describe the potential environmental variability that may there occur in the future (Gordon 2003). Over the next 15 years, we will attempt to quantify the relationship between the extent of ice cover, local conditions, and total primary production along the icecovered Victoria Land coast and the findings may be used in future studies to develop scenarios of reduced ice at sites further south. In this paper, we describe initial findings of a four season survey (between 1999-2004) of biomass and

a.

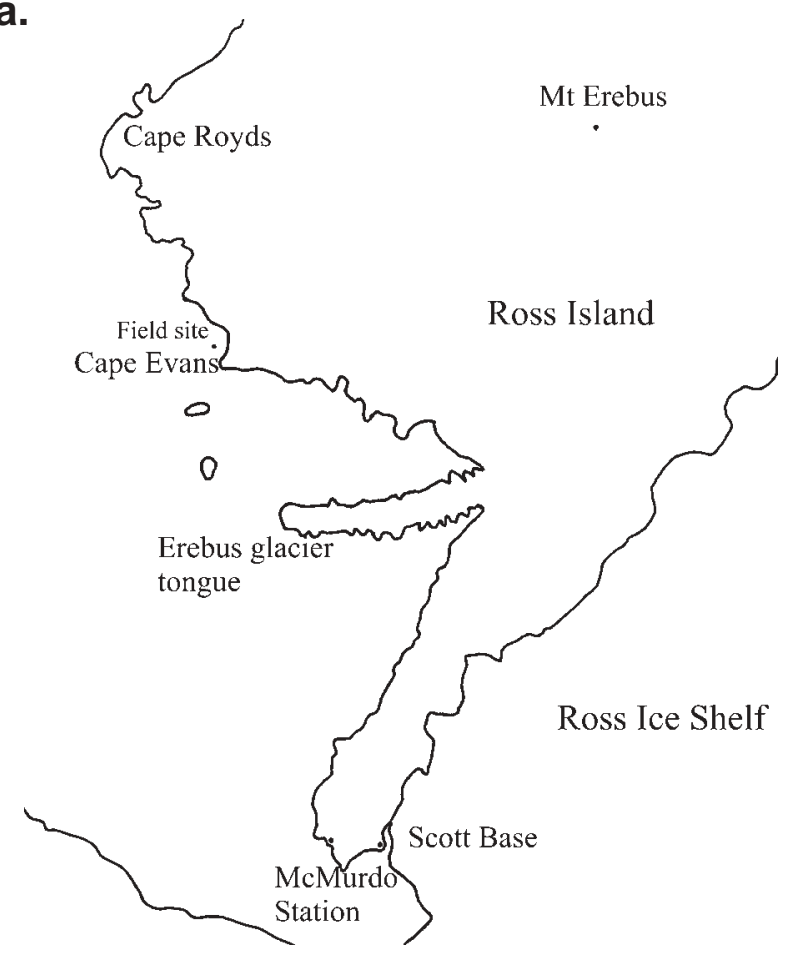

biodiversity at Cape Evans, Ross Island and Cape Hallett, Victoria Land, Antarctica. This study is the first under the LGP framework, to contrast microalgal community structure and biomass from these two most separated areas. We examine samples from within the sea ice and from the underlying water column in three ice types: the first year fast ice at Cape Evans and two-year and first year fast ice at Cape Hallett.

\section{Material and methods}

Sampling sites

Cape Evans, Ross Island $\left(77^{\circ} 38^{\prime} \mathrm{S}, 166^{\circ} 24^{\prime} \mathrm{E}\right.$, about $150 \mathrm{~m}$ from Scott's Hut, Fig. 1a): Samples of first year fast ice were collected every 3-4 days over a two week period from 28 October-12 November 1999, and again at the same location between 16 October-2 November 2001. The ice thickness was $1.9 \mathrm{~m}$ in 1999 and $2.1 \mathrm{~m}$ in 2001 and in both years there was minimal snow cover. In 1999 an additional site was sampled from the same ice formation but with $10 \mathrm{~cm}$ snow cover. The water current under the sea ice in both years was negligible. This site was chosen as no ice platelets were present on the underside of the sea ice.

Cape Hallett, Victoria Land $\left(72^{\circ} 19^{\prime} \mathrm{S}, 170^{\circ} 13^{\prime} \mathrm{E}\right.$, Fig. 1 b): Repeat samplings were done at each of four sites at intervals of 3-4 days from 19 November-12 December 2003, and from 14 November-2 December 2004. In the region around

b.

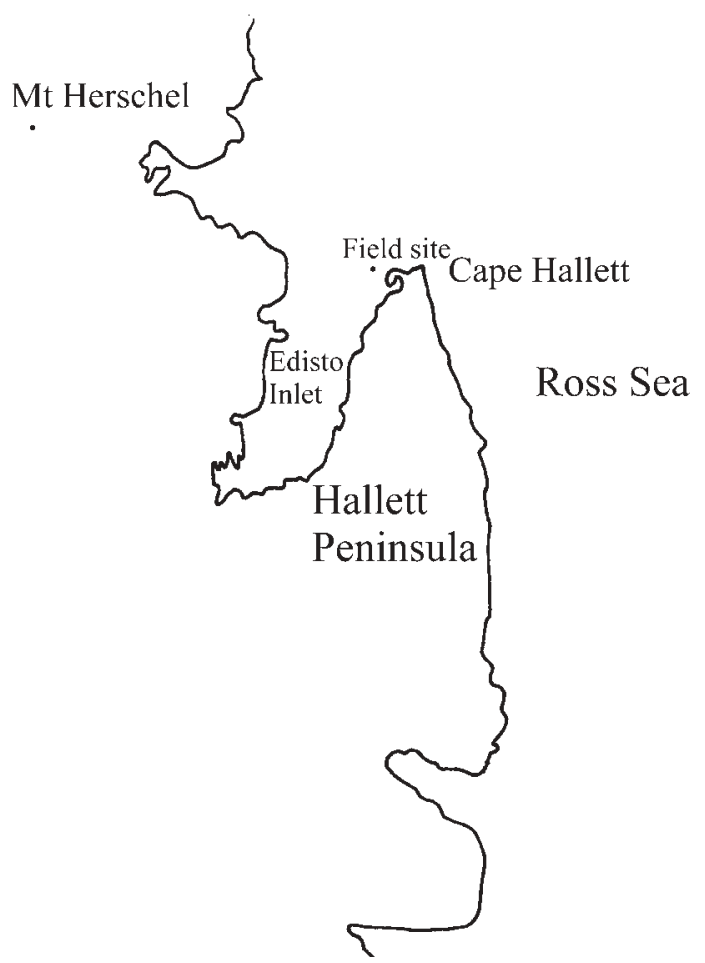

Fig. 1. Maps showing sampling sites at a. Cape Evans, and b. Cape Hallett. 

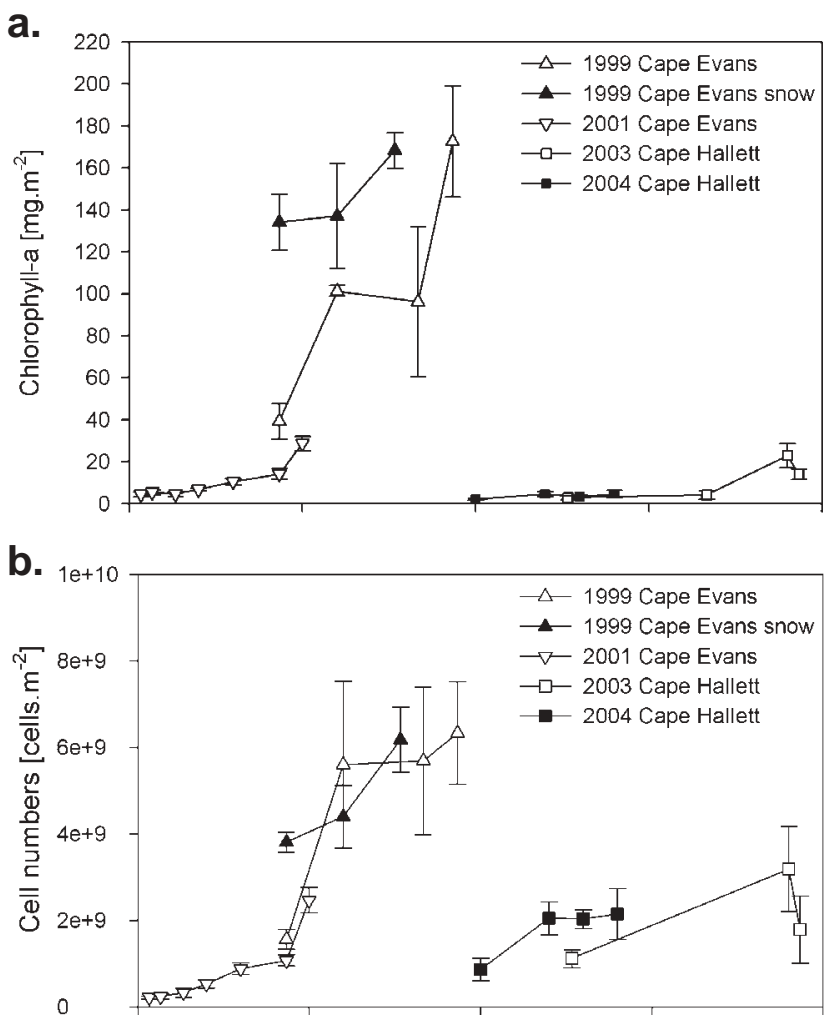

Fig. 2. Comparison of algal biomass measurements in the sea ice with respect to sampling date for Cape Evans (1999 and 2001) and Cape Hallett (2003 and 2004) for a. Chlorophyll a, b. cell numbers. Data are mean and standard error of the mean.

Seabee Hook, the ice ranged in thickness from 1.15 to $1.85 \mathrm{~m}$ in both years. The ice was two years old in 2003 and broke out at the end of the 2003/2004 season. New ice formed over winter 2004. Some old ice drifted into the region and became embedded in the new ice, but these regions were avoided in the 2004 collections. The samples collected over 2003 and 2004 in the same region therefore provide us with data from first year sea ice and from twoyear-old ice. An additional physical factor governing ice conditions was the presence of a strong current in the water under the ice. The direction and strength of this current was unpredictable and appeared to result from an eddy forming in Edisto Inlet in a current running south to north along the main coastline. This current appeared very strong in 2003 although it was not measured. Icebergs embedded in the sea ice may have modulated its flow and direction. In 2004 the current was less and was not as variable as in the previous year, perhaps due to the fact that there were less icebergs embedded in the ice. The current caused scouring of the under surface of the ice in both years.

\section{Ice cores}

Sea ice algae were collected from $130 \mathrm{~mm}$ diameter cores cut from the bottom of sea ice at several locations using a
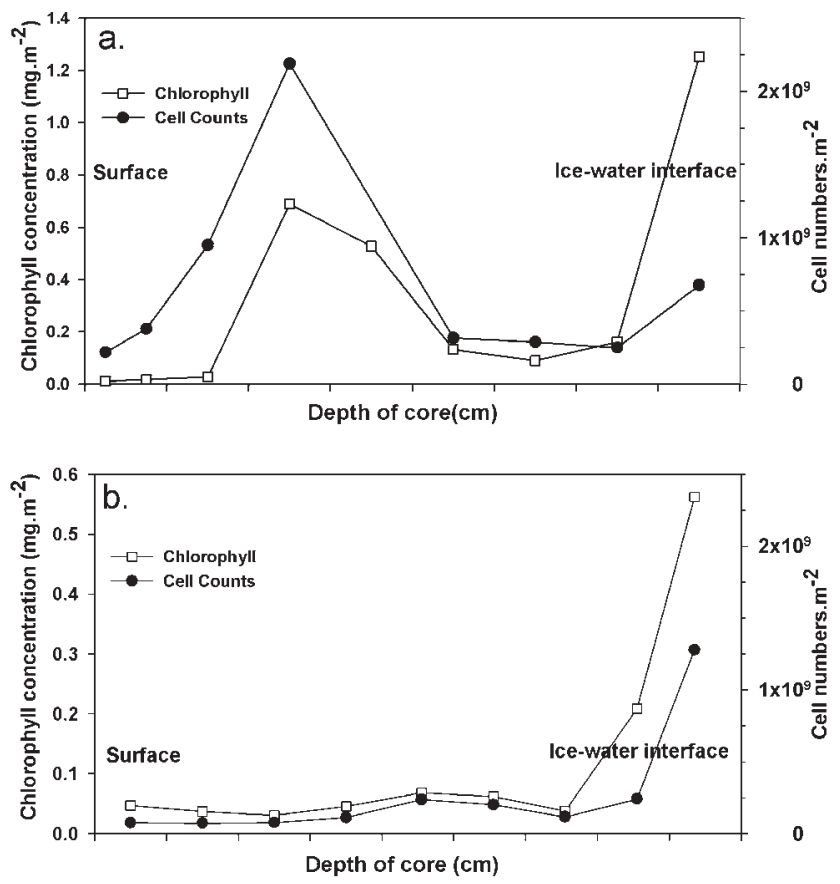

Fig. 3. Chlorophyll concentrations and microalgal cell counts with respect to sea ice profile depth for an individual core extracted from Cape Hallett in a. 2003, and b. 2004.

Kovaks (Kovaks, USA) ice corer. As far as possible these sites represented the range of conditions of sea ice in the region. Four to five sites were chosen that were typical of the fast ice in the region in terms of snow cover and ice thickness. Samplings were done in the centre of an ice formation that was at least $100 \mathrm{~m}$ across. With the exception of one site at Cape Evans in 1999, all sites were clear of snow. At Cape Evans 15 cores were sampled from clear ice in 1999 (3-5 replicates, 4 time points), and seven in ice with $10 \mathrm{~cm}$ snow cover (2-3 replicates, 3 time points). In 2001 36 cores were sampled from clear ice $(n=4-6$, seven time points). The 2003 sampling programme at Cape Hallett consisted of 49 cores from different locations near Sea Bee Hook. Of these, 16 cores were taken from the same location ( $1.5 \mathrm{~m}$ ice, no snow cover) at intervals over the period of the study as representative of the Cape Hallett region ( $n=4,4$ time points). In 2004, 53 cores were collected from different locations over the period of the study. Of these, 16 cores ( $n=4,4$ time points) were from the same snow free location ( $1.35 \mathrm{~m}$ ice) were again chosen as representative of the region.

During collection, the cores were protected from light damage by performing all operations underneath a black sheet and transferring the cores into black plastic tubes. Cores were then cut into 10 or $20 \mathrm{~cm}$ sections to a standard size (usually $40 \times 40 \times 100 \mathrm{~mm}$ ). Each section was then melted into three times the quantity of filtered seawater $\left(35 \%, 0.22 \mu \mathrm{m},-1.8^{\circ} \mathrm{C}\right)$ under low-light $(<1 \mu \mathrm{mol}$ photons 
a.

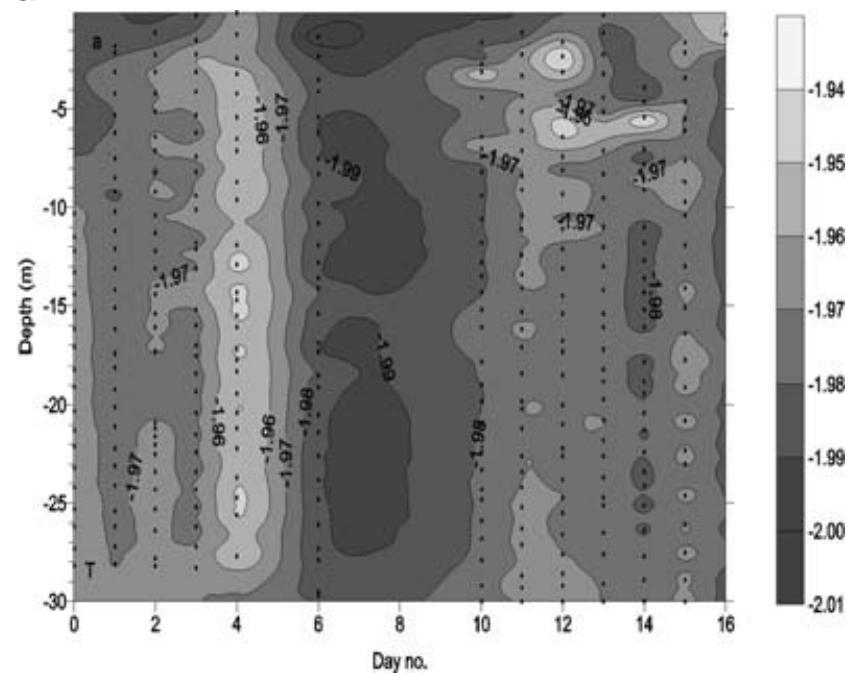

b.

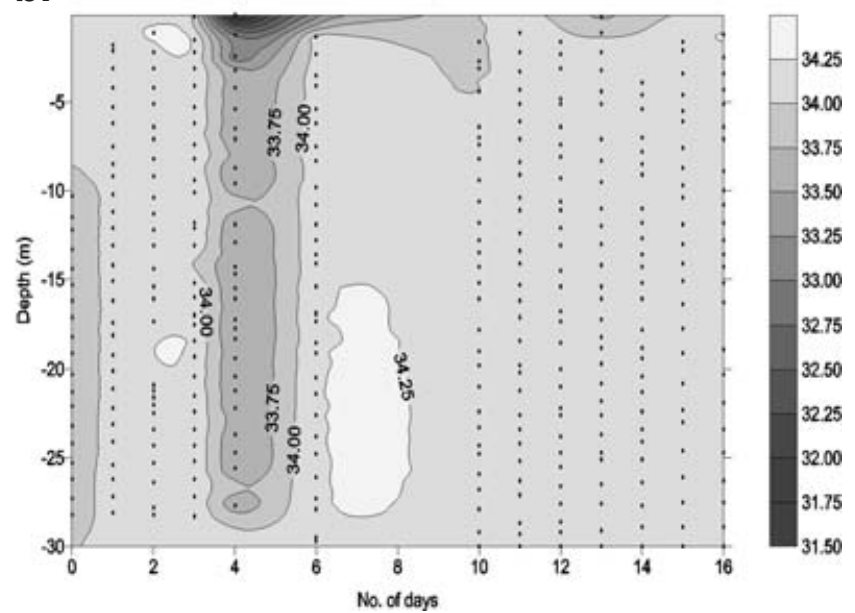

C.

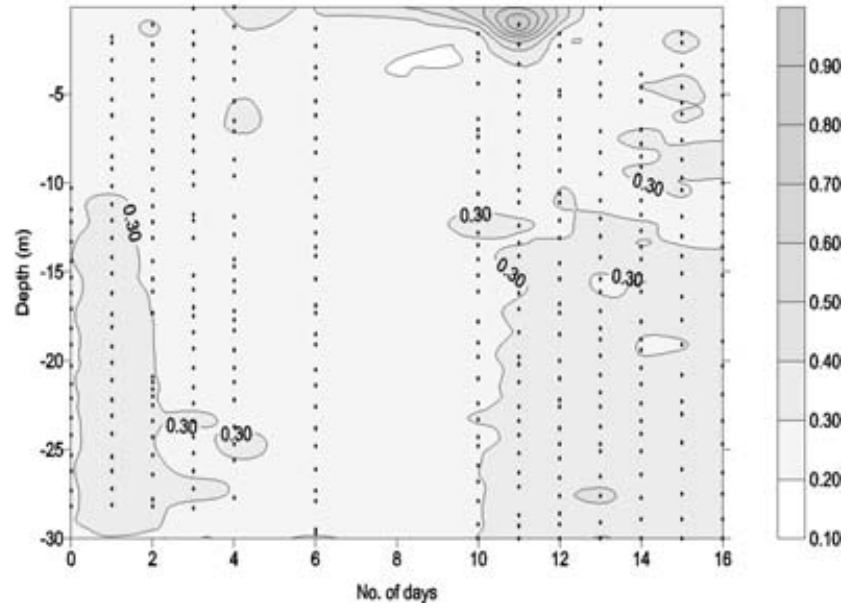

Fig. 4. Composite contour images of CTD (conductivity, temperature, depth) casts (dotted lines) deployed under the ice to a depth of $30 \mathrm{~m}$ at Cape Evans between 18 October and 3 November 2001 showing a. temperature, b. salinity, c. Chl $a$. a.

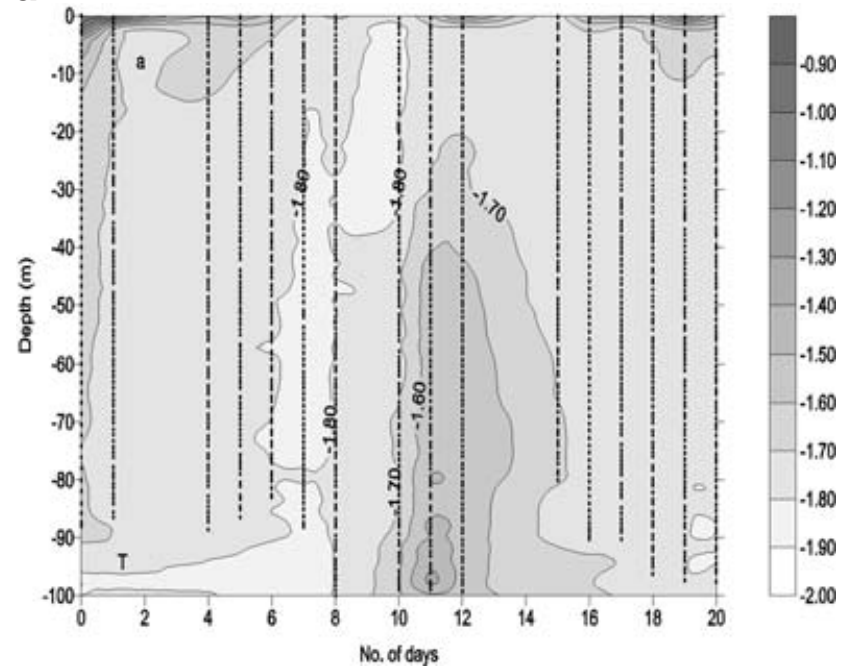

b.

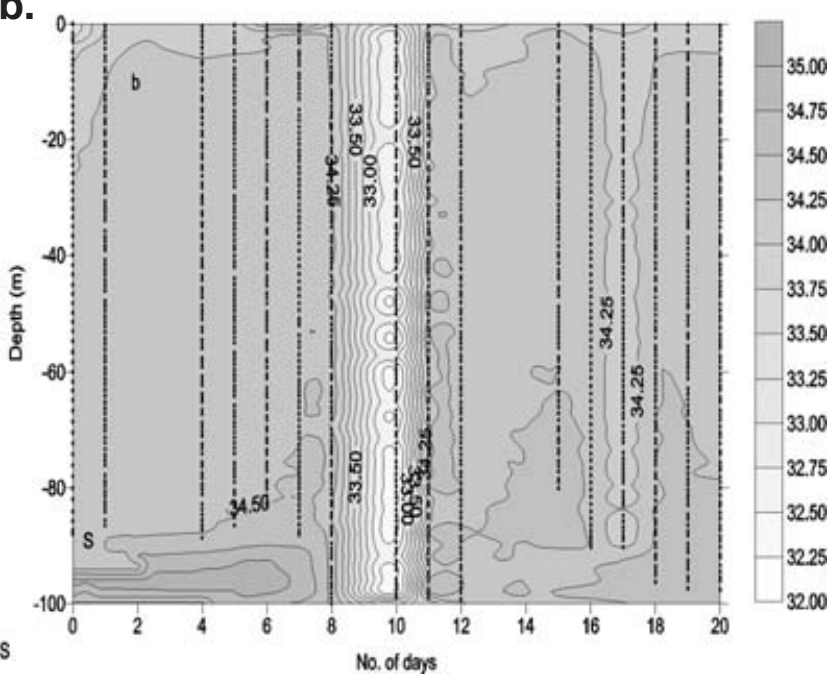

C.

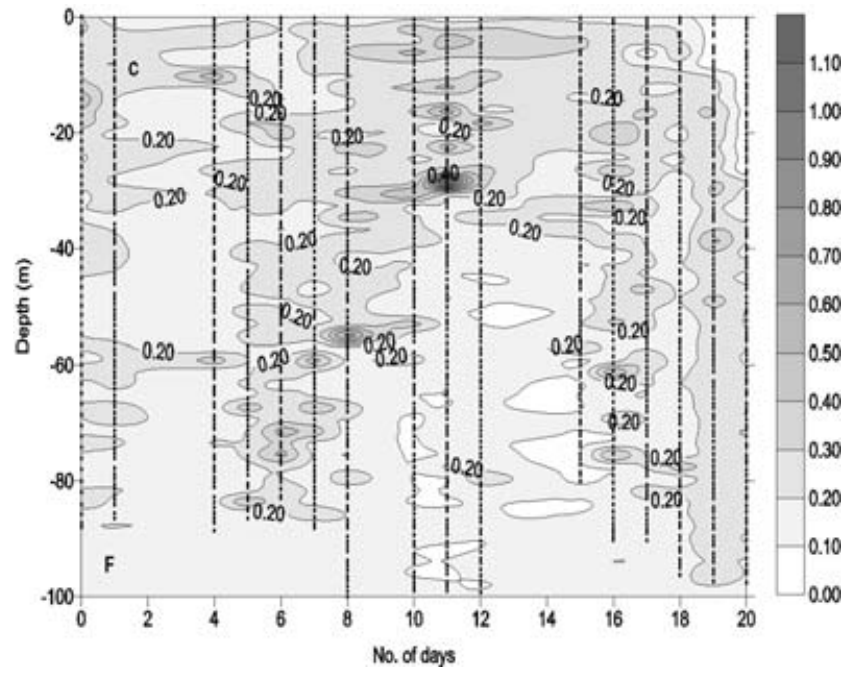

Fig. 5. Composite contour images of CTD casts (dotted lines) deployed under the ice to a depth of $100 \mathrm{~m}$ at Cape Hallett between 15 November and 5 December 2004 showing a. temperature, b. salinity, c. Chl $a$. 
$\mathrm{m}^{-2} \mathrm{~s}^{-1}$ ) over a period of 12 hours (following the procedures in Ryan et al. 2002, 2004). After melting, the sample was divided into subsamples and analysed for Chl $a$ and the species present were identified and counted

\section{Surface brine sampling}

Algae growing within the brine channels near the surface of the sea ice were collected at Cape Hallett. A shallow hole $20 \mathrm{~cm}$ diameter and $20 \mathrm{~cm}$ deep was drilled in the surface of the ice with a powered ice auger. The hole was immediately covered with a black sheet and left for 10-15 min. After this time, the brine that had drained into the hole from the surrounding ice was collected into opaque containers, and maintained at $0^{\circ} \mathrm{C}$ until use. At all times during sampling, light shock was avoided by performing all operations under the black sheet.

\section{CTD profiles}

A conductivity, temperature, depth (CTD) profiling instrument was used at Cape Evans (Applied Microsystems Ltd, Model STD-12 Plus, with attached Chl $a$ flurometer, Wetstar model no: 9706013) and at Cape Hallett (RBR Instruments with an attached $\mathrm{Chl} a$ fluorometer). Profiles were conducted at each location by lowering the instrument through a $400 \mathrm{~mm}$ hole in the ice to the bottom (30 m, Cape Evans) or to $100 \mathrm{~m}$ (Cape Hallett). Depth zero on the CTD plots (Figs $4 \& 5$ ) refer to the surface of the water in the hole. The water depth at the Cape Hallett site was c. $150 \mathrm{~m}$. Profiles were performed each day through the same hole for the duration of each field season unless logistics prevented their collection. At Cape Evans the casts were made at solar noon (approximately 1:30 pm local time at this longitude), and a similar collection regime was attempted at Cape Hallett but the distance of the profile site from our field camp often prevented a solar noon collection. Recorded depth-time data were analysed using Surfer for Windows, v6, software. Although the instrument was lowered to the full $100 \mathrm{~m}$ of cable at Cape Hallett, the actual depth achieved was usually less than this as the strong current drove the instrument sideways and therefore to a lesser depth.

\section{Chlorophyll a determinations}

100-300 $\mathrm{ml}$ samples of the melted core section were filtered onto $47 \mathrm{~mm} \mathrm{GF} / \mathrm{F}$ filters and extracted in $10 \mathrm{ml}$ of methanol over 12 hours in the dark at $4^{\circ} \mathrm{C}$. The Chl $a$ concentration was measured on a digital fluorometer (Turner $10 \mathrm{AU}$ ) using the acidification protocol of Evans et al. (1987).

\section{Cell density and identifications}

A $10 \mathrm{ml}$ sample of each core section was fixed in $0.5 \%$ glutaraldehyde and returned to New Zealand for analysis of cell density and for species identifications. A $0.5 \mathrm{ml}$ aliquot of this material was counted on an inverted microscope (Zeiss) using a special settling chamber and phase contrast optics until a minimum of 200 cells per sample were identified and counted. Live samples of the Cape Evans material were examined in the field on an upright microscope (Kyowa) using standard microscope slide preparations for species identifications. Fixed samples were retained and returned to New Zealand for total cell counts as described above.

\section{Phytoplankton sampling}

Water samples for phytoplankton were collected with a water bottle lowered through the same hole as for the CTD measurements and closed by a messenger weight at 5,25 and $50 \mathrm{~m}$. Samples were split for Chl $a$ analysis and for species identification and cell numbers. The cells were fixed with $0.5 \%$ glutaraldehyde and counted as for the sea ice cores and a minimum of 100 cells were counted. Chlorophyll $a$ was measured after filtering $300 \mathrm{ml}$ seawater, then analysed as described above for ice cores. Data were compared using Student's t-test.

\section{Results}

Ice cores

In 1999 and 2001 all of the ice cores at Cape Evans consisted of congelation ice, and no platelet ice was observed at the bottom. The ice was first year ice, with no snow cover, $1.9 \mathrm{~m}$ thick in 1999 and $2.1 \mathrm{~m}$ thick in 2001. This ice was clear of snow cover for at least one month before our visits in both years. In an additional site in 1999, the ice had a snow cover of approximately $10 \mathrm{~cm}$. At Cape Hallett all ice cores in both years consisted of congelation ice, with no platelet ice observed at the bottom. In 2003 the ice was approximately $1.5 \mathrm{~m}$ thick multi-year ice, while in 2004 it was of similar thickness but was first year ice. All sites chosen for study at Cape Hallett were clear of snow cover and remained so throughout our field season. The Cape Hallett sampling areas were in a similar condition, for at least one week prior to our study in each year.

\section{Physical conditions in the water column beneath the ice}

Cape Evans 2001: During the period of measurement, the water mass beneath the ice had a salinity of between 33.7 and $34.2 \%$ and a temperature of -1.95 to $-1.99^{\circ} \mathrm{C}$. Fluctuations in water salinity and temperature were minor and the water masses remained similar for the duration of the experiment (Fig. 4a \& b). Water currents under the sea ice were negligible.

Cape Hallett 2004: Compared to Cape Evans, the water 
mass at Cape Hallett beneath the ice had a slightly higher salinity, ranging between 34.2 and $34.4 \%$, and the temperature was slightly warmer at -1.5 to $-1.8^{\circ} \mathrm{C}$ during most of the period of study, with only minor fluctuations with time. An influx of warmer, low salinity water took place after about day 10 (25 November) of the sampling period (Fig. 5a \& b). This water mass was detected from the surface to a depth of $100 \mathrm{~m}$ and may have flushed some of the biomass from the inlet, particularly at depth.

\section{Sea ice algal biomass}

Cape Evans: The bottom surface of the ice was covered in a dense layer of algal cells, with some cells of Berkelya adeliensis suspended beneath the ice in the latter part of the collection period in 1999. No platelet ice was present in either year. In 1999 the snow-covered site had Chl $a$ concentrations varying from 134 to $168 \mathrm{mg} \mathrm{Chl} a \mathrm{~m}^{-2}$ as the season progressed. Areal $\mathrm{Chl} a$ concentrations in the clear ice site increased from $34 \mathrm{mg}$ to $173 \mathrm{mg} \mathrm{Chl} a \mathrm{~m}^{-2}$ (Fig. 2a), in the bottom section of the ice core $(P<0.01)$. The snow and clear site chlorophyll levels were not significantly different when compared on similar days $(P<0.05)$, with the exception of the earliest snow covered measurement $(P<0.05)$. Cell numbers in both types of ice were similar, ranging from 1.6 to $6.3 \times 10^{9}$ cells $\mathrm{m}^{-2}$ (Fig. $2 \mathrm{~b}$ ), and the increase over the season in the clear site was significant $(P<0.01)$.

In 2001 areal Chl $a$ concentrations increased over the collection period from a minimum of $4.4 \mathrm{mg} \mathrm{Chl} a \mathrm{~m}^{-2}$ to a maximum of $28.7 \mathrm{mg} \mathrm{Chl} a \mathrm{~m}^{-2}$ for the 36 cores $(P<0.001)$ (Fig. 2a). Total cell numbers per core increased over an order of magnitude during the season in 2001 from $0.21-2.5$ x $10^{9}(P<0.001)$ (Fig. 2b). The majority of the algae were found in the bottom layer, although this was only assessed visually as no profile cores were taken.

Cape Hallett: The bottom surface of the ice was smooth and eroded, with no platelets attached. Algal cells present were embedded in the ice and there were no algae suspended beneath the ice as was found in the later part of the season at Cape Evans. Areal Chl $a$ concentrations in annual ice in 2003 increased significantly during the period of measurements from a minimum of 2.9 to a maximum of $22.9 \mathrm{mg} \mathrm{Chl} \mathrm{a} \mathrm{m}^{-2}(P<0.01)$ (Fig. 2a), however the increase in cell number from 1.1 to $1.8 \times 10^{9}$ cells $\mathrm{m}^{-2}$ (Fig. 2b) was not significant. The highest concentration of Chl $a$ was evident at the ice water interface, but there was a substantial peak of chlorophyll, at about $50 \mathrm{~cm}$ from the surface of this core (Fig. 3a), indicating that this ice was two seasons old. This was also evident in the cell counts, where the number of cells in the middle of the core was actually higher than at the ice water interface. Depth integrated areal $\mathrm{Chl} a$ concentrations, calculated on four profiles from similar ice taken early in the sampling period, were $2.1 \pm 0.7 \mathrm{mg} \mathrm{m}^{-2}$ (mean \pm standard error). On a volume basis this equated to $1.4 \pm 0.4 \mathrm{mg} \mathrm{m}^{-3}$. The percentage of Chl $a$ in the bottom $10 \mathrm{~cm}$ of these profiles was $18.4 \pm 3.2 \%$.

In 2004, the areal Chl $a$ concentration varied from a minimum of $2.1 \mathrm{mg} \mathrm{Chl} a \mathrm{~m}^{-2}$ to a maximum of $4.6 \mathrm{mg}$ Chl $a \mathrm{~m}^{-2}$ (Fig. 2a). This small increase over the period of study was not significant. In the same samples the change in cell numbers from 0.9 to $2.1 \times 10^{9}$ also was not significant (Fig. 2b). The profile from the 2004 ice cores (Fig. 3b) illustrates annual fast ice as there was no peak in chlorophyll or cell numbers mid way through the ice core. Depth integrated areal Chl $a$ concentrations based on three similar profiles was $2.7 \pm 0.6 \mathrm{mg} \mathrm{m}^{-2}$ or $2.1 \pm 0.6 \mathrm{mg} \mathrm{m}^{-3}$.

Table I. Percentage species composition, Cape Evans 1999 mean (standard error).

\begin{tabular}{|c|c|c|c|c|c|c|c|c|c|c|}
\hline Snow & $28 \mathrm{Oct}$ & 5 & $3.5(1.2)$ & 29.7 (3.9) & $6.94(1.4)$ & $6.3(0.6)$ & $14.9(1.5)$ & $32.2(3.0)$ & $2.3(0.4)$ & $4.2(0.8)$ \\
\hline \multirow{3}{*}{ Clear ice } & $3 \mathrm{Nov}$ & 2 & $17.1(13.9)$ & $24.2(6.6)$ & $9.0(2.6)$ & $3.8(0.9)$ & $15.7(5.7)$ & $26.7(2.6)$ & $0.1(0.1)$ & $3.5(0.7)$ \\
\hline & 9 Nov & 3 & $29.2(12.4)$ & $13.0(2.9)$ & $9.2(2.6)$ & $4.0(1.3)$ & $28.8(6.2)$ & $11.8(2.5)$ & $0.3(0.2)$ & $3.8(1.5)$ \\
\hline & $12 \mathrm{Nov}$ & 4 & $22.7(3.7)$ & $14.8(1.7)$ & $8.9(1.7)$ & $4.5(0.5)$ & $28.9(4.4)$ & $16.9(2.7)$ & $0.2(0.0)$ & $3.1(0.3)$ \\
\hline
\end{tabular}

Table II. Percentage species composition, Cape Evans 2001 mean (standard error).

\begin{tabular}{|c|c|c|c|c|c|c|c|c|c|c|}
\hline & & $\mathrm{n}$ & $\begin{array}{l}\text { Berkeleya } \\
\text { adeliensis }\end{array}$ & $\begin{array}{l}\text { Entomoneis } \\
\text { kjellmannii }\end{array}$ & $\begin{array}{l}\text { Fragilariopsis } \\
\text { curta }\end{array}$ & $\begin{array}{c}\text { Navicula } \\
\text { glaciei }\end{array}$ & $\begin{array}{l}\text { Nitzschia } \\
\text { lecointei }\end{array}$ & $\begin{array}{l}\text { Nitzschia } \\
\text { stellata }\end{array}$ & $\begin{array}{c}\text { Pleurosigma } \\
\text { solinarum }\end{array}$ & Other \\
\hline \multirow[t]{5}{*}{ Clear ice } & 19 Oct & 4 & 0.0 & $32.4(6.0)$ & $23.1(13.8)$ & $17.3(4.6)$ & $0.6(0.4)$ & $14.5(4.0)$ & $1.6(0.7)$ & $10.6(1.8)$ \\
\hline & $24 \mathrm{Oct}$ & 4 & $0.4(0.4)$ & $32.1(8.4)$ & $24.2(10.3)$ & $13.0(2.8)$ & $1.7(0.6)$ & $14.3(5.5)$ & $2.2(0.7)$ & $12.4(3.6)$ \\
\hline & $28 \mathrm{Oct}$ & 4 & 0.0 & $34.0(3.5)$ & $6.2(3.8)$ & $21.4(2.6)$ & $3.3(0.8)$ & $16.4(4.0)$ & $1.9(0.6)$ & $12.8(2.8)$ \\
\hline & $30 \mathrm{Oct}$ & 4 & $0.1(0.1)$ & $40.8(8.2)$ & $10.9(1.5)$ & $16.5(2.1)$ & $3.6(1.8)$ & $16.6(2.1)$ & $1.8(0.4)$ & $9.9(1.4)$ \\
\hline & $2 \mathrm{Nov}$ & 4 & $0.0)$ & $31.5(2.4)$ & $8.1(2.4)$ & $22.2(3.8)$ & $5.0(1.5)$ & $24.5(4.2)$ & $2.1(0.7)$ & $7.7(2.6)$ \\
\hline
\end{tabular}


The percentage of Chl $a$ in the bottom $10 \mathrm{~cm}$ of these profiles was $36.5 \pm 13.5 \%$. The presence of multiyear ice in 2003 did not significantly alter the Chl $a$ content of the bottom ice as yields were similar in different years at the same time of the year. However, as is readily seen in Fig. 2a, Chl $a$ levels in Cape Hallett are approximately two orders of magnitude lower that at an equivalent time of the year at Cape Evans $(P<0.001)$.

\section{Ice algal species compositions}

Microscopic examination of the algal samples showed that different species compositions existed in the two different locations (Tables I-IV). At Cape Evans in 1999 the bottom ice community under clear ice was a mixture of pennate diatoms including Nitzschia stellata Manguin, Nitzschia lecointei Van Heurck, Entomoneis kjellmanii (Cleve) and to a lesser extent also Fragilariopsis curta (van Heurck) Hustedt. Berkeleya adeliensis Medlin was present as threads hanging off the bottom surface of the sea ice, and this species increased in concentration over the two week period in early November1999 (Table 1). In a separate set of collections, species compositions were determined for a $10 \mathrm{~cm}$ snow covered region of sea ice from the same formation at Cape Evans. As can be seen in Table I, the species composition in this region was very similar to the adjacent snow free plot. In 2001 the collections were taken approximately two weeks earlier than in 1999 (Table II). The species composition observed at the end of this period closely resembled that at the start of the 1999 collections (compare similar dates in Tables I \& II).

At Cape Hallett, the algal communities from the bottom of the ice and from the surface brine were examined. Pennate diatoms dominated the species composition of the bottom ice algal communities in each year, with $N$. stellata, F. curta, and Cylindrotheca closterium (Ehrenberg) typically comprizing more than $50 \%$ of all samples. In 2003, the most abundant species was F. curta (Table III). In 2004 the same three species dominated, although the a.

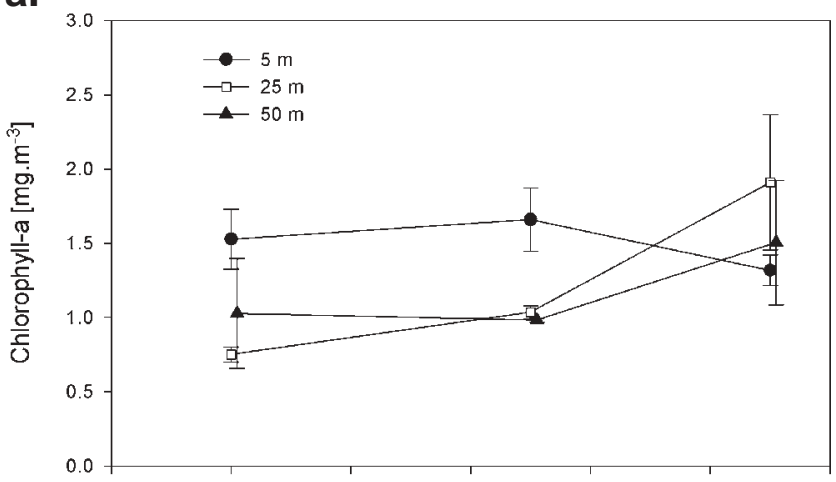

b.

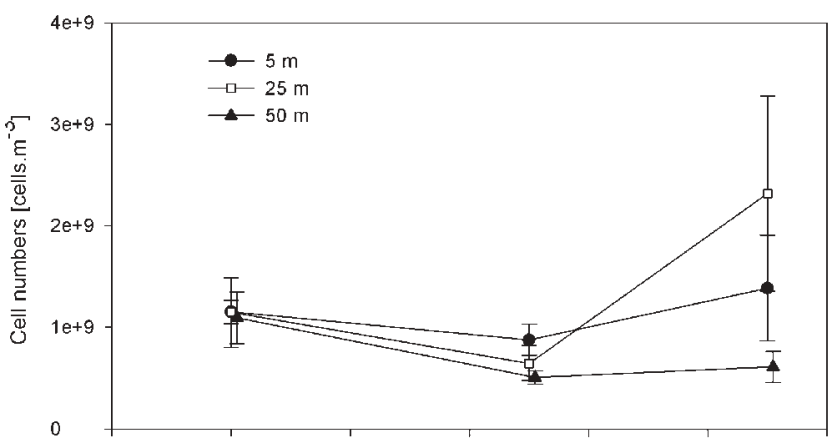

Fig. 6. Chlorophyll concentrations and cell counts of phytoplankton sampled from deployments to 5,25 , and $50 \mathrm{~m}$ under annual sea-ice between 20 November and 2 December 2004 at Cape Hallett, a. Chl $a$, b. cell counts. Data are mean and standard error of the mean.

relative proportions changed, and $N$. stellata became the most abundant species (Table IV). Other species abundant at Cape Evans were either not found at all (B. adeliensis) or were present in very low concentrations (E. kjellmanii). Samples were also analysed from brine extracted from the surface of the sea ice. The species composition here was quite different, and was dominated by F. curta, Chaetoceros sp. and the dinoflagellate Polarella glacialis Montresor, Procaccani \& Stoecker. In 2004, P. glacialis was especially

Table III. Percentage species composition, Cape Hallett 2003 mean (standard error).

\begin{tabular}{lcccccrrrr}
\hline & $n$ & Chaetoceros sp. & Cylindrotheca spp & $\begin{array}{c}\text { Fragilariopsis } \\
\text { curta }\end{array}$ & $\begin{array}{c}\text { Navicula } \\
\text { glaciei }\end{array}$ & $\begin{array}{r}\text { Nitzschia } \\
\text { lecointei }\end{array}$ & $\begin{array}{c}\text { Nitzschia } \\
\text { stellata }\end{array}$ & Polarella sp & Other \\
\hline Bottom ice & 3 & 0.0 & $29.0(25.3)$ & $43.1(18.7)$ & $1.1(1.1)$ & $4.1(2.4)$ & $11.2(6.4)$ & $5.8(5.8)$ & $11.1(3.5)$ \\
Surface ice & 2 & $0.4(0.4)$ & $12.0(2.0)$ & $32.3(7.7)$ & $4.4(1.0)$ & $10.5(3.5)$ & $7.1(1.0)$ & $10.7(3.9)$ & $22.7(8.8)$ \\
\hline
\end{tabular}

Table IV. Percentage species composition, Cape Hallett 2004 mean (standard error).

\begin{tabular}{lccccccrrr}
\hline & $\mathrm{n}$ & Chaetoceros sp. & Cylindrotheca spp & $\begin{array}{c}\text { Fragilariopsis } \\
\text { curta }\end{array}$ & $\begin{array}{c}\text { Navicula } \\
\text { glaciei }\end{array}$ & $\begin{array}{r}\text { Nitzschia } \\
\text { lecointei }\end{array}$ & $\begin{array}{c}\text { Nitzschia } \\
\text { stellata }\end{array}$ & $\begin{array}{c}\text { Polarella sp } \\
\text { Other }\end{array}$ \\
\hline Bottom ice & 3 & 0.0 & $9.6(2.5)$ & $25.0(5.2)$ & 0.0 & $6.1(2.5)$ & $55.9(5.4)$ & 0.0 & $3.5(2.6)$ \\
Surface ice & 3 & $21.7(5.11)$ & $1.0(0.6)$ & $12.3(0.4)$ & 0.0 & 0.0 & $0.9(0.5)$ & $56.5(7.8)$ & $7.5(3.1)$ \\
Seawater $(5 \mathrm{~m})$ & 2 & $0.1(0.1)$ & $16.9(5.0)$ & $33.9(9.4)$ & 0.0 & $0.4(0.4)$ & $15.2(3.9)$ & $0.3(0.3)$ & $26.5(5.8)$ \\
\hline
\end{tabular}


abundant. All other species were present in low concentrations (Table IV).

\section{Phytoplankton in the water column}

Cape Evans 2001: Phytoplankton samples were not taken, hence we do not know whether growth had started in the water column below the ice. Increased biomass just below the ice, evident in the CTD profiles (Fig. 4c) late in the period, was probably due to ice algae falling off the ice during sampling the evening before. A slightly higher biomass could be seen in the deepest $15-20 \mathrm{~m}$ in the beginning and end of the sampling period. This elevated biomass rising from the bottom was most probably due to re-suspension of bottom sediments containing algal cells.

Cape Hallett 2004: The species composition in the water column was similar to that in the bottom ice, although the proportion of $N$. stellata was less (Table IV). Phaeocystis sp. was sometimes present in seawater samples but this was rare. The degree of chlorophyll present in the water column at the time of the first CTD cast (15 November) suggests that algal biomass was already present beneath the ice (Fig. 5c). Both chlorophyll and cell numbers (expressed in volumetric rather than areal units) are given in Fig. 6 for water bottle samples collected at three different depths on 22 November 2004. These data show that algae were present through the water column at approximately the same concentrations regardless of depth (1-1.5 $\left.\mathrm{mg} \mathrm{Chl} a \mathrm{~m}^{-3}\right)$. Comparison with the data from a CTD cast made on the same day (Fig. 5c) allows a rough calibration of the fluorescence reading on the CTD instrument at approximately 1 fluorescence unit $=5.7 \mathrm{mg} \mathrm{Chl} a \mathrm{~m}^{3}$. Integrating the fluorescence profile for 22 November 2004 for the full $100 \mathrm{~m}$ gives 20.4 fluorescence units, or approximately $115 \mathrm{mg} \mathrm{Chl} a$ for one square metre of the water column. The depth integrated volumetric data from the profiles in Fig. 3c at a similar collection time show $2 \mathrm{mg}$ in a square metre of $1.6 \mathrm{~m}$ thick ice. These calculations indicate that sea ice contains approximately $2 \%$ of the biomass in the total ice/water column on 22 November 2004.

\section{Discussion}

McMurdo Sound in the Ross Sea is an area where sea ice algae have been extensively studied over a period of 25 years. Despite this there is little known of their composition and inter-annual variability in relation to physical conditions of the ice matrix. This study has compared sea ice algal communities in a well-known area of the southern Ross Sea with those in a much lesser known part of the northern Ross Sea. To our knowledge this is the first report of the sea ice algal community at Cape Hallett. The ice at the two locations was of variable age. At Cape Evans, both in 1999 and 2001, annual fast ice c. $2.0 \mathrm{~m}$ thick covered the study area after breakout of the ice in the previous January. At Cape Hallett, satellite data collected from 1979 to 2000 suggest that sea ice generally remains in Edisto Inlet after the rest of the ice along the coast from Cape Adare to Coulman Island has broken out. The average date that icefree water eventually appears in Edisto Inlet is January $27 \pm$ two weeks (SD), and while on average this ice-free period extends until 2 March, in some years the ice does not completely clear at all (Falconer \& Pyne 2000). This appears to have been the case in 2003, as the ice in Edisto Inlet in late spring of this year was multiyear ice, with numerous trapped icebergs. The ice broke out in January 2004 , and as a result there was first year ice for our study in late 2004.

A number of authors have investigated the water current systems in McMurdo Sound and circulation patterns are generally considered complex and variable (Gilmore 1963, Heath 1977). Several processes interact to control the currents within and around the Sound with wind and tidal activity being the most significant, leading to currents highly variable in time and space (Heath 1977, Barry \& Dayton 1988). The Cape Evans sampling site was in the lee of the prevailing currents in McMurdo Sound and the currents in the study area were negligible in both years. This site was chosen to avoid platelet ice cover on the underside of the ice as it is difficult to collect samples from plateletcovered sea ice by ice corer without losing biomass.

Further north, the currents of water masses entering the Ross Sea in a west-north-west direction over the shelf are intensified in front of Victoria Land due to the narrowing of the continental shelf and typical current flows of $8-8.5 \mathrm{~m} \mathrm{~s}^{-1}$ are higher than elsewhere in the Ross Sea (Picco et al. 1999). Tidal currents are also very strong in this area (Johnson \& van Woert 2006). Hence the hydrographical conditions at our two sampling sites at Cape Evans and Cape Hallet were quite different with regard to water currents, and this had a significant effect on ice algal abundance.

\section{Ice algal biomass}

Arrigo et al. (2003) compiled a detailed survey of the pack ice algal communities in the Ross Sea. They reported mean $\mathrm{Chl} a$ abundances in the Ross Sea of $2.53 \mathrm{mg} \mathrm{Chl} a \mathrm{~m}^{-2}$. We have noted similar levels in pack ice on the outer coast west of the Ross Sea in the vicinity of the Mertz glacier $(2.08 \mathrm{mg}$ Chl $a \mathrm{~m}^{-2}$, McMinn et al. in press). Arrigo et al. (2003) noted that these levels are lower than those measured in other pack ice habitats particularly in the Weddell Sea. Standing crops in fast ice in the Ross Sea are typically much higher than in pack ice at around $200 \mathrm{mg}$ Chl $a \mathrm{~m}^{-2}$ (Palmisano \& Sullivan 1983, Arrigo et al. 1998), and levels can rise considerably higher than this (e.g. $1.9{\mathrm{~g} \mathrm{Chl} a \mathrm{~m}^{-2}}^{-2}$ has been recorded in fast ice on the west coast of the Ross 
Sea by Riaux-Gobin et al. 2003). We confirm typical McMurdo Sound levels in the bottom $10 \mathrm{~cm}$ of fast ice at Cape Evans, where levels rose to $173 \mathrm{mg} \mathrm{Chl} a \mathrm{~m}^{-2}$ in mid November of 1999. The lower biomass measured in 2001 is most probably due to the earlier sampling period (Fig. 2a).

At a similar time of the year at Cape Hallett (mid November), the standing crop of bottom ice Chl $a$ was only $0.1 \mathrm{mg} \mathrm{Chl} a \mathrm{~m}^{-2}$. One month later on 15 December, the Chl $a$ content at Cape Hallett had still reached only one fifth that at Cape Evans one month earlier in the season (36.8 mg. Chl $a \mathrm{~m}^{-2}$ ).

The snow cover was minimal at both study sites, but the ice thickness was less at Cape Hallett (1.5 m vs $2 \mathrm{~m}$ at Cape Evans). The huge difference in $\mathrm{Chl} a$ standing stocks at the two locations is unlikely to be due to differences in ice thickness or age (Arrigo et al. 2003), and is more likely to be due to local conditions. The start of the 2001 sampling at Cape Evans yielded low biomass, and biomass increased steadily through the season. Losses of biomass were not observed in the period of the study, however, it should be noted that strong reductions in biomass late in the season have been observed at Cape Evans in previous years (McMinn et al. 2000). At Cape Evans the water current beneath the ice was typically very low, to non existent, while at Cape Hallett currents were very strong. The Chl $a$ profiles obtained from Cape Hallett in 2004 are typical of annual fast ice floes where the biomass is concentrated in the bottom 20-30 cm of the ice. In 2003, a peak in Chl a levels and cell counts in the middle of the profiles indicated two year ice (Fig. 3a). However, in both years the total chlorophyll biomass was low, both in annual and in twoyear old fast ice. These biomasses are similar to those recorded one month earlier in the season at Cape Evans. There was no significant interannual variability in overall biomass between 2003 and 2004 at Cape Hallett. In 2004 there was no significant increase in biomass during the period of sampling, while in 2003, levels only increased in the last two samplings just prior to the breakup of the ice. Sampling at Cape Hallett was performed later in the season than at Cape Evans, and we cannot rule out the possibility that an ice algal peak may have occurred at Cape Hallett before sampling started. The underside of the ice in all Cape Hallett core samples was scoured and eroded, indicating that ablation of the ice algal community may have occurred. We believe, due to the similarity between the 2003 and 2004 season, and the consistently low biomasses throughout the sampling period, that high currents caused ablation of sea ice algal biomass from the bottom of the ice, and this reduced the apparent standing stock of sea ice algae in Cape Hallett. Considering the high currents in the region, this may be a persistent phenomenon along the coast of Victoria Land, where the environment for ice algal growth may be very different from that in the McMurdo Sound area.

The primary variables influencing sea ice algal growth are elevated salinity, access to nutrients, and irradiance. Net photosynthesis occurs during spring and summer where snow cover is less than c. $0.3 \mathrm{~m}$ (Grossi et al. 1987, Arrigo et al. 2003). Given the variability in thickness of both snow and ice, the irradiance that penetrates to microbial communities exhibits high variability. While a negative relationship between Chl $a$ accumulation and snow depth might generally be expected, recent findings in the Arctic suggest that productivity may be enhanced by some degree of snow cover (Mundy et al. 2005). These authors observed maximum biomass under intermediate snow cover, while a decline in algal biomass and sloughing of cells under thin snow cover was correlated with desalination of the aboveice cover. Deep snow will modify shade acclimation of algal cells but since drifting snow is a common feature of the Antarctic coastal topography, snow depth may not necessarily give an accurate history of previous light conditions (Garrison \& Buck 1991). The area of ice at Cape Evans with snow cover examined in 1999 was in the lee of the Cape and remained the same thickness during the entire sampling period. Similarly, the snow free area chosen for study had been clear of snow for the month prior to our study and remained clear for its duration. The similarity in species composition and biomass (Table I) between the snow and snow-free areas suggests that both communities were well acclimated to ambient light levels.

\section{Species composition}

Species composition was relatively consistent from year to year at Cape Evans, and taking the two years into account it can be seen that the dominant species were Entomoneis kjellmannii, Nitzschia stellata, Navicula glaciei and Fragilariopsis curta. Nitzschia lecointei and Pleurosigma solinarum were also common. In 1999 the tube dwelling diatom Berkeleya adeliensis increased in abundance in the latter part of the season. This was due to the development of tubes of cells suspended from the bottom of the ice, and they remained because there was little or no current and no platelet ice formed in this location. This is consistent with previous compositions (e.g. Palmisano \& Sullivan 1983, McMinn 1997, McMinn et al. 2000). Entomoneis kjellmannii and $N$. stellata are both usually associated with interstitial ice (McConville \& Wetherbee 1983), while species such as $B$. adeliensis form strand communities, and seem to prefer higher light (snow-free ice) (McMinn 1997). The same suite of species is also present in fast ice in East Antarctica (Watanabe et al. 1990, Archer et al. 1996, RiauxGobin et al. 2003) and in the Ross Sea pack ice (Arrigo et al. 2003, Garrison et al. 2005) although dominant species vary.

At Cape Hallett the dominant species were F. curta and $N$. stellata. Cylindrotheca closterium and $N$. lecointei were common, while the larger celled species, which were dominant at Cape Evans, were almost completely absent. It 
is interesting to note that the surface brine algal community composition was different both taxonomically and in biomass, especially in 2004 when there was a high concentration of the dinoflagellate Polarella glacialis. This taxon was also found in abundance in the surface of sea ice at Terra Nova Bay $\left(76^{\circ} \mathrm{S}\right)$ (Andreoli et al. 2000). Similar observations have been noted by Archer et al. (1996) in fast ice at Davis Station in East Antarctica.

The observed difference in species composition between the two sampling sites reflects different environmental conditions. The strong currents in the Cape Hallett area prevent the formation of the productive brine channels typically found on the underside of fast ice, and may provide unfavourable conditions for the larger ice algal species such as Entomoneis kjellmannii and Berkeleya adeliensis. The latter, forming strands, would naturally be removed by the currents, although this species may not be present in the area as it was not observed in water samples. Entomoneis kjellmannii was found in low numbers in some cores. The prevalence of small-celled species such as F. curta at Cape Hallett has resulted in a bottom-ice algal community that is more similar to pack ice (Garrison et al. 2005, McMinn et al. in press) than to fast ice. Furthermore, the low Chl $a$ levels at Cape Hallett are more typical of pack ice at the same latitude (Arrigo et al. 2003) than of fast ice.

Since the phytoplankton in the water column at Cape Hallett were of a similar species composition to that in the ice above (Table IV), and that they are well mixed through the entire $100 \mathrm{~m}$ profile (Figs $5 \mathrm{c} \& 6 \mathrm{a}$ ), it is likely that the algae in the seawater are enriched from the ablated bottom ice community. Fragilariopsis curta is the most abundant diatom in the western Ross Sea and Terra Nova Bay (Nelson \& Smith 1986, Andreoli et al. 1995, Nuccio et al. 1999, Fonda Umani 2005), giving rise to some of the most prominent ice edge blooms in Antarctica (Knox 1990). Seeding from the ice is highly likely, as observed also in the Weddell Sea (Hegseth \& Quillfeldt 2002). In McMurdo Sound, the spring bloom is composed almost entirely of Phaeocystis antarctica (Knox 1990), thus the ice algal communities in this area do not seem to seed pelagic blooms. One reason for this could be that more of the dominating species are obligate ice algae, and not suitable for pelagic growth. Another possibility is that Phaeocystis is brought into the area from outside (Rivkin \& Voytek 1987), and that this happens before the ice starts to melt. By that time, the Phaeocystis bloom is already dominating. Diatoms are also observed in the pelagic blooms of McMurdo Sound. However, the common species Thalassiosira scotia and Fragilariopsis kerguelensis are mainly pelagic (Scott \& Thomas 2005), although the latter is sometimes found in sea ice (Archer et al. 1996).

\section{Relative contributions of sea ice and seawater communities to total biomass}

Our chlorophyll data from the water column at Cape Hallett (Fig. 6a) and the CTD chlorophyll profiles (Fig. 5c) show that phytoplankton were present through the water column to at least $100 \mathrm{~m}$ and distributed relatively evenly throughout. A CTD cast was made on November 22 (Fig. 5c), and immediately afterward, Chl $a$ concentrations were determined by the extraction method from water bottle samples (Fig. 6a). Assuming that the primary productivity in the benthos below our site and in the water over $100 \mathrm{~m}$ deep was negligible, we estimate that the ice contributed c. $2 \%$ of the total Chl $a$ in the full ice-water column at Cape Hallett on that day. Duplicate measurements on other days gave a similar percentage (data not shown). Given that the current under the ice was fairly constant and strong, and that the CTD profiles show little change in Chl $a$ over the three week period of the study, it is reasonable to assume that this represents the contribution of the ice to the total water column standing crop at this time. This contribution from the ice is unusually low for fast ice, which normally contains approximately $20-30 \%$ of total water column standing crop (Arrigo et al. 1998).

An understanding of the spatial and temporal dynamics of Antarctic sea ice and the associated biotic communities is fundamental to quantifying Southern Ocean productivity and the trophodynamics of the Antarctic coastal ecosystem. Projected warming for polar regions over the 21 st century is likely to reduce the extent and thickness of annual sea ice (Kerr 2006, Velicogna \& Whar 2006), which will alter both the light and salinity regimes to which the microbial community is exposed. These events could modify the significant contribution that the sea ice microbial community makes to Southern Ocean primary production (Arrigo et al. 2003). Large-scale environmental factors including solar and ultraviolet-B radiation, temperature and day length vary with latitude and these variables may play a dominant role in future sea ice productivity, although we know little about how different microbial systems will respond (Ryan et al. 2004). Biodiversity and growth rates of Antarctic marine micro-organisms may serve as valuable markers for environmental monitoring, due to their short generation times and simple cellular structure (Jochem 2000).

Our initial findings show large differences in biomass and community composition within fast ice in two locations separated by five degrees of latitude along the coast of Victoria Land. While these sites were selected to be of similar ice thickness and proximity to shore, and were collected at similar (though not the same) times of the year, the pattern of change was opposite to that expected for a north-south gradient. There were significant differences in the physicochemical characteristics of each site, and primary among these were differences in local water 
currents. It is therefore important to stress that local conditions play a crucial role in determining production. In future studies along the Victoria Land coastline, we will attempt to quantify the extent to which ice-driven dynamics control the structure and function of the sea ice ecosystem and design biophysical process models describing the productivity of the microbial populations at each site.

\section{Acknowledgements}

We thank Antarctica NZ for logistic support and in particular the LGP team, Shulamit Gordon, Rachel Brown and Gus McAlister for their efficient construction and management of the field camp at Cape Hallett. Thanks too to the Scott Base staff, for their help in preparation for the field. Ken Ryan acknowledges the support of the Foundation of Research Science and Technology contract no (VICX0219). Else Hegseth's contribution was supported by The Norwegian College of Fishery Science, University of Tromsø. Andrew McMinn acknowledges the financial and logistical support of an Australian Antarctic Science grant and financial support from the Australian Research Council. Peter Ralph thanks the Australian Research Council grant number DP0344067. Joe Buchanan performed some of the microscopy work, and Ulf Normann prepared the CTD figures. We thank the reviewers for their helpful comments.

\section{References}

Andreoli, C., Tolomio, C., Moro, I., Radice, M., Moschin, E. \& Bellato, S. 1995. Diatoms and dinoflagellates in Terra Nova Bay (Ross Sea-Antarctica) during austral summer 1990. Polar Biology, 15, $465-475$

Andreoli, C., Moro, I., LaRocca, N., Dalle Valle, L., Masiero, L., Rascio, N. \& Dalla Vecchia, F. 2000. Ecological, physiological and biomolecular surveys on microalgae from Ross Sea (Antarctica). Italian Journal of Zoology, 67, 147-156.

Archer, S.D., Leakey, R.J.G., Burkill, P.H., Sleigh, M.A. \& Appleby, C.J. 1996. Microbial ecology of sea ice at a coastal Antarctic site: community composition, biomass and temporal change. Marine Ecology Progress Series, 135, 179-195.

Arrigo, K.R. \& Sullivan, C.W. 1992. The influence of salinity and temperature co-variation on the photophysiological characteristics of Antarctic sea ice microalgae. Journal of Phycology, 28, 746-756.

Arrigo, K.R., Robinson, D.H. \& Sullivan, C.W. 1993. A high resolution study of the platelet ice ecosystem in McMurdo Sound, Antarctica: photosynthetic and bio-optical characteristics of a dense microalgal bloom. Marine Ecology Progress Series, 98, 173-185.

Arrigo, K.R., Worthen, D., Schnell, A. \& Lizotte, M.P. 1998. Primary production in Southern Ocean waters. Journal of Geophysical Research, 103, 15 587-15 600 .

Arrigo, K.R., Robinson, D.H., Dunbar, R.B., Leventer, A.R. \& Lizotte, M.P. 2003. Physical control of chlorophyll $a$, POC, and TPN distributions in the pack ice of the Ross Sea, Antarctica. Journal of Geophysical Research, 108, doi: 10.1029/2001JC001138.

ARrigo, K.R. \& Thomas, D.N. 2004. Large scale importance of sea ice biology in the Southern Ocean. Antarctic Science, 16, 471-486.
BARRY, J.P. \& DAYTON, P.K. 1988. Current patterns in McMurdo Sound, Antarctica and their relationship to local biotic communities. Polar Biology, 8, 367-376.

Buck, K.R., Bolt, P.A., Bentham, W.N. \& Garrison, D.L. 1992. A dinoflagellate cyst from Antarctic sea ice. Journal of Phycology, 28, $15-18$.

Evans, C.A., O'Reilly, J.E. \& Thomas, J.P. 1987. A handbook for the measurement of chlorophyll $a$ and primary production. College Station, TX: Texas A\&M University, 114 pp.

FAlCONER, T. \& PYNe, A. 2000. Sea ice analysis for proposed hydrographic survey - Cape Hallett, Cape Adare and Possession Islands. (LINZ project number 1017). Antarctic Research Centre, School of Earth Sciences, Victoria University of Wellington.

Fonda Umani, S., Monti, M., Bergamasco, A., Cabrini, M., De Vittor, C., Burba, N. \& Del Negro, P. 2005. Plankton community structure and dynamics versus physical structure from Terra Nova Bay to Ross Ice Shelf (Antarctica). Journal of Marine Systems, 55, 31-46.

Garrison, D.L. 1991. Antarctic sea ice biota. American Zoologist, 31, $17-33$.

Garrison, D.L. \& BucK, K.R. 1991. Surface-layer sea ice assemblages in Antarctic pack ice during the austral spring: environmental conditions, primary productivity and community structure. Marine Ecology Progress Series, 75, 161-172.

Garrison, D.L., Gibson, A., Coale, S.L., Gowing, M.M., Okolodkov, Y.B., Fritsen, C.H. \& JefFeries, M.O. 2005. Sea-ice microbial communities in the Ross Sea: autumn and summer biota. Marine Ecology Progress Series, 300, 39-52.

GiLmore, A.E. 1963. Hydrological heat and mass transport across the boundary of the ice shelf in McMurdo Sound, Antarctica. New Zealand Journal of Geology and Geophysics, 6, 402-422.

Gordon, S. 2003. LGP Initial Environmental Evaluation. Christchurch: Antarctica New Zealand, 35 pp. [Unpublished].

Grossi, S.M. \& Sullivan, C.W. 1985. Sea ice microbial communities. V. The vertical zonation of diatoms in an Antarctic fast ice community. Journal of Phycology, 21, 401-409.

Grossi, S.M., Kottmeier, S.T., Moe, R.L., Taylor, G.T. \& Sullivan, C.W. 1987. Sea ice microbial communities. VI. Growth and primary production in bottom ice under graded snow cover. Marine Ecology Progress Series, 35, 153-164.

Heath, R.A. 1977. Circulation across the ice shelf edge in McMurdo Sound, Antarctica. In DunBar, M.J., ed. Polar oceans. Calgary: Arctic Research Institute, 129-149.

Hegseth, E.N. \& Von Quillfeldt, C.H. 2002. Low phytoplankton biomass and ice algal blooms in the Weddell Sea during the ice-filled summer of 1997. Antarctic Science, 14, 231-243.

Howard-Williams, C., Peterson, D., Lyons, W.B., Cattaneo-Vietti, R. \& GoRDON, S. 2006. Measuring ecosystem response in a rapidly changing environment: the Latitudinal Gradient Project. Antarctic Science, 18, 465-471.

JoCHEM, F.J. 2000. Probing the physiological state of phytoplankton at the single-cell level. Scientia Marina, 64, 183-195.

Johnson, E.S. \& VAN WoERT, M.L. 2006. Tidal currents of the Ross Sea and their time stability. Antarctic Science, 18, 141-154.

KerR, R.A. 2006. A worrying trend of less ice, higher seas. Science, 311, 1698-1701.

KnOX, G.A. 1990. Primary production and consumption in McMurdo Sound, Antarctica. In Kerry, K.R. \& Hempel, G., eds. Antarctic ecosystems: ecological change and conservation. Berlin: Springer, $115-128$

Legendre, L., Ackley, S.F., Dieckmann, G.S., Gulliksen, B., Horner, R., Hoshiai, T., Melnikov, I.A., Reeburgh, W.S., Spindler, M. \& Sullivan, C.W. 1992. Ecology of sea ice biota. 2. Global significance. Polar Biology, 12, 429-444. 
McConville, M.J. \& Weatherbee, R. 1983. The bottom ice microalgal community from annual ice in the inshore waters of East Antarctica. Journal of Phycology, 19, 431-439.

McMinn, A. 1997. Species succession in fast ice algal communities: a response to UV-B radiation? Korean Journal of Polar Research, 8, $47-52$.

McMinn, A. \& Ashworth, C. 1998. The use of oxygen microelectrodes to determine the net production by an Antarctic sea ice algal community. Antarctic Science, 10, 39-44.

MCMinn, A., Ashworth, C. \& RYAn, K.G. 1999a. Growth and productivity of Antarctic sea ice algae under PAR and UV irradiances. Botanica Marina, 42, 401-407.

McMinn, A., Skerratt, J., Trull, T., Ashworth, C. \& Lizotte, M. 1999 b. Nutrient stress gradient in the bottom $5 \mathrm{~cm}$ of fast ice, McMurdo Sound, Antarctica. Polar Biology, 21, 220-227.

McMinn, A., Ashworth, C. \& Ryan, K.G. 2000. In situ net primary productivity of an Antarctic fast ice bottom algal community. Aquatic Microbial Ecology, 21, 177-185.

McMinn, A., Ryan, K.G., RalPh, P. \& Pankowski, A. In press. Spring sea ice photosynthesis, primary productivity and biomass distribution in eastern Antarctica, 2002-2004. Marine Biology.

Mock, T. \& THOMAs, D.N. 2005. Recent advances in sea-ice microbiology. Environmental Microbiology, 7, 605-619.

Mundy, C.J., BARBER, D.G. \& Michel, C. 2005. Variability of snow and ice thermal, physical and optical properties pertinent to sea ice algae biomass during spring. Journal of Marine Systems, 58, 107-120.

Nelson, D.M. \& Smith, W.O. 1986. Phytoplankton bloom dynamics of the western Ross Sea ice edge - II. Mesoscale cycling of nitrogen and silicon. Deep-Sea Research, 33, 1389-1412.

Nuccio, C., Innamorati, M., Lazzara, L., Mori, G. \& Massii, L. 1999. Spatial and temporal distribution of phytoplankton assemblages in the Ross Sea. In Faranda, F.M., Guglielmo, L. \& Ianora, A., eds. Ross Sea ecology. Berlin: Springer, 231-245.

Palmisano, A.C. \& Sullivan, C.W. 1983. Sea ice microbial communities (SIMCO) 1. Distribution, abundance and primary production of ice microalgae in McMurdo Sound, Antarctica in 1980. Polar Biology, 2, 171-177.

Palmisano, A.C. \& GARRISON, D.L. 1993. Microorganisms in Antarctic sea ice. In Friedman, E.I., ed. Antarctic microbiology. New York: WileyLiss, 167-218.

Palmisano, A.C., Kottmeier, S., Moe, R. \& Sullivan, C.W. 1985. Sea ice microbial communities. IV. The effect of light perturbation on microalgae at the seawater interface in McMurdo Sound, Antarctica. Marine Ecology Progress Series, 21, 37-45.

Peterson, D. \& Howard-Williams, C., eds. 2001. The Latitudinal Gradient Project. Christchurch: Antarctica New Zealand, Special Publication, $46 \mathrm{pp}$.
Picco, P., Beergamasco, A., Demimicheli, L., Manzella, G., Meloni, R. \& PASCHINI, E. 1999. Large-scale circulation features in the Central and Western Ross Sea (Antarctica). In Faranda, F., Guglielmo, L. \& IANORA, A., eds. Ross Sea ecology. Berlin: Springer, 95-105.

Riaux-Gobin, C., Treguer, P., Poulin, M. \& Vetion, G. 2003. Nutrients, algal biomass and communities in land-fast ice and seawater off Adélie Land (Antarctica). Antarctic Science, 12, 160-171.

Rivkin, R.B. \& VoYteK, M.A. 1987. Photoadaptations of photosynthesis and carbon metabolism by phytoplankton from McMurdo Sound, Antarctica. 1. Species-specific and community responses to reduced irradiances. Limnology and Oceanography, 32, 249-259.

RyAN, K.G. \& BeAgLehole, D. 1994. Ultraviolet radiation and bottom-ice algae: Laboratory and field studies from McMurdo Sound, Antarctica. Antarctic Research Series, 62, 229-242.

Ryan, K.G., McMinn, A., Mitchell, K.A. \& Trennery, L. 2002. Mycosporine like amino acids in Antarctic sea ice algae, and their response to UVB radiation. Zeitschrift fur Naturforshhung, 57, 461-477.

RYAN, K.G., RalPh, P. \& MCMinn, A. 2004. Acclimation of Antarctic bottom-ice algal communities to lowered salinities during melting. Polar Biology, 27, 679-686.

Scott, F.J. \& Thomas, D.P. 2005. Diatoms. In Scott, F.J. \& Marchant, H.J., eds. Antarctic marine protists. Canberra: Australian Biological Resources Study \& Hobart: Australian Antarctic Division, 13-201.

Stoecker, D.K., BuCK, K.R. \& PutT, M. 1991. Photosynthetic dinoflagellates and their cyst characteristics of the land fast ice. Antarctic Journal of the United States, 26, 143-144.

Sullivan, C.W., Palmissano, A.C., Kottmeier, S. \& Moe, R. 1982. Development of the sea ice microbial community in McMurdo Sound. Antarctic Journal of the United States, 17, 155-157

Sullivan, C.W., Palmisano, A.C., Kottmeier, S., McGrath Grossi, S. \& MoE, R. 1985. The influence of light on growth and development of the sea-ice microbial community of McMurdo Sound. In SiEgFried, W.R., Condy, P.R. \& Laws, R.M., eds. Antarctic nutrient cycles and food webs. Berlin: Springer, 78-83.

Thomas, D.N. \& Dieckmann, G.S. 2002. Antarctic sea ice - a habitat for extremophiles. Science, 295, 641-644.

Thomas, D.N., Kattner, G., Engbrodt, R., Giannelli, V., Kennedy, H., HaAs, C. \& Dieckmann, G.S. 2001. Dissolved organic matter in Antarctic sea ice. Annals of Glaciology, 33, 297-302.

Trenerry, L.J., McMinn, A. \& RyAn, K.G. 2002. In situ oxygen microelectrode measurements of bottom-ice algal production in McMurdo Sound, Antarctca. Polar Biology, 25, 72-80.

VelicognA, I. \& WAHR, J. 2006. Measurement of time-variable gravity show mass loss in Antarctica. Science, 311, 1754-1756.

Watanabe, K., SaOH, H. \& Hoshiai, T. 1990. Seasonal variation in ice algal assamblages in the fast ice near Syowa Station in 1983/84. In Kerry, K.R. \& Hempel, G., eds. Antarctic ecosystems: ecological change and conservation. Berlin: Springer, 136-142. 